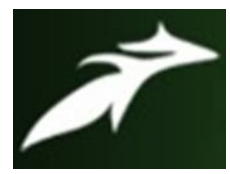

Tamim Fazily, International Journal of Advances in Agricultural Science and Technology,

Vol.8 Issue.3, March-2021, pg. 10-26

ISSN: 2348-1358

Impact Factor: 6.057

NAAS Rating: 3.77

\title{
Effect of Sowing Dates and Seed Rates on Growth and Yield of Different Wheat Varieties: A Review
}

\author{
Tamim Fazily \\ Associate Professor at Department of Agronomy, Agriculture Faculty of Baghlan University, Pulikumri-3601, \\ Baghlan, Afghanistan \\ Email: tamim.fazily@yahoo.com \\ DOI: 10.47856/ijaast.2021.v08i3.002
}

\begin{abstract}
Sowing time, seeding rate and variety are the key responsible among many other factors enhancing the growth and yield of wheat. Wheat is one of the most important leading crops of Afghanistan and the world. Despite higher yield potential the average yield of wheat in Afghanistan is very less than most of countries of the world. Besides other responsible factors for lower yield introduction of new high yielding potential varieties, optimum seeding rates and their adaptability with new environment are the most important factors which decide the growth, yield and quality of wheat. Changes of optimum temperature during vegetative or reproductive growth of wheat adversely affect the initiation and duration of crop in different pheno-phases and finally yield of wheat. Wheat as winter crop requires definite temperature and light for optimum growth. Too early sowing when temperature is above the optimum produce poor plants and even higher seeding rate cannot compensate low yield. Under late sown conditions, wheat faces low temperature in the earlier stage and high temperature in the later stages of the growing season and requires favorable moisture for better growth and development which causes yield reduction. At optimum temperature, early sowing with optimum plant population enhances the growth and nutrient uptake of wheat resulting in higher crop production. The optimum seeding rate depends on temperature, sowing date and type of varieties. The seed rate increases with delay in sowing due to poor plant stand, where higher seeding rate produces more plants in unit area resulting in higher intra-crop competition hereby affecting the yield and production cost. Similarly lower plant population produces lower grain yield due to higher vegetative growth and space wastages. Therefore to minimize the effect of temperature variation, proper sowing date, optimum plant population and varietal selection according to environmental conditions are the best noncash options to increase the growth, yield traits and yield of the wheat.
\end{abstract}

Keywords: Sowing date, Seed rate, Wheat variety, growth, yield.

\section{Introduction}

Wheat (Triticum aestivum L.) is one of the most widely cultivated cereal crops and stable food of many countries in the world. Wheat crop with is remarkable adaptability in many agro-climates stands second in respect to area of production in the world and provides about 20 per cent of total food calories 


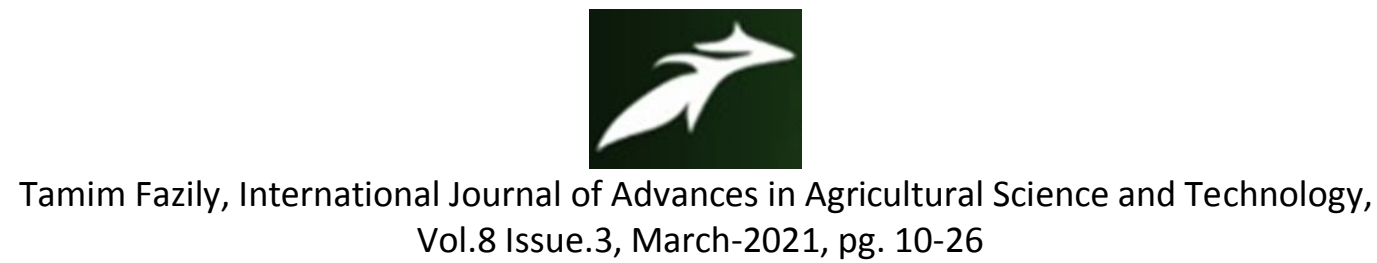

ISSN: 2348-1358

Impact Factor: 6.057

NAAS Rating: 3.77

for human being. Despite higher yield potential, the average yield of wheat in Afghanistan is very less than most countries of the world. There are many factors responsible for low yield such as cultivation of old varieties, sowing date, low seed rate, low fertilizer rates etc. The environment under which crop is grown creates a tremendous impact on growth, development and yielding ability of wheat crop. Wheat crop requires optimum conditions during its growth and development to attain good yield. High temperature is one of the most important abiotic environmental factors during grain filling and may influence both the quantity and quality of the yield. High temperature after anthesis causes a reduction in grain filling (Wardlaw and Moncur, 1995; Veisz et al., 2008), more rapid apoptosis and the earlier attainment of harvest maturity (Altenbach et al., 2003). Under late sown conditions, wheat faces low temperature in the earlier part and high temperature in the later part of the growing season and requires favorable moisture for better growth and development. Therefore, efforts ought to be made to minimize the effect of temperature variation caused due to changed sowing date by choosing appropriate wheat varieties which can synchronize its temperature requirement. The introduction of new varieties with high yield potential and wide range of adaptability is an important factor responsible for enhancing wheat production. Different varieties respond differently to applied nutrient fertilizer and hence differ in their yield potential. Similarly cultivars differ significantly regarding fertile tillers, spike length, number of grains per spike, grain and straw yield (Naeem, 2001; Ali et al., 2010).

Optimum seed rate is one of the most important production factors for higher grain yield as well as for quality crop. Indiscriminate use of seeding rate not only increases production costs but usually decrease wheat grain yield. Optimum seeding rate is particularly important in wheat production because it is under the farmer's control in most cropping systems (Slafer and Satorre, 1999). Optimum plant densities are greatly affected by areas, climatic conditions, soil, sowing time, and varieties (Darwinkel et al. 1977). If optimal seeding rates exceed, yield reductions often occur (Beuerlein and Lafever, 1989; Harrison and Beuerlein, 1989). Previous researches indicated that seeding rates significantly affected biological yield (Ayaz et al. 1997. Higher seeding rates compensate for reduced tiller development and promote more main stem spikes which can be favorable, especially for cultivars that tend to produce fewer tillers (Coventry et al. 1993; Staggenborg et al. 2003). A close relationship exists between wheat stands and yield components (Zhen-Wen et al. 1988). Keeping in view of above facts, this review was carried out to explain effect of sowing dates and seed rate on growth and yield of different wheat varieties.

\section{Effect of sowing dates and variety on growth and yield of wheat}

Osmani et al. (2020) conducted field experiments for two consecutive spring seasons of 2017 and 2018 at experimental farm of Kabul University, to find out the adoptability of four local spring wheat varieties i.e., V1-Zardana Baghlan, V2- Sorkha-Andarab, V3-Safida-Kunduz and V4-Safida-Andarab varieties under Agro-climate conditions of Kabul. They observed that during both the seasons SafidaAndarab (V4) produced shorter plant height but significantly higher number of tillers, spikes, grains per spike, spike length, test weight and grain yield (4.17 and $4.43 \mathrm{t} / \mathrm{ha})$ of wheat, which all these parameters were on par with variety of Safida-Kunduz during both the consecutive years. Fazily et al. (2019) conducted a field experiment during winter season of 2015-16 on sandy loam soils of Poz-e-Ishan Research Farm of Agricultural Faculty of Baghlan University, to find out the performance of four wheat varieties (Milad 013, Bakhtar 013, Chonta 01, Kabul 013) on different dates of sowing (25th November, 11th December, 26th December and 11th January 2016) under irrigated condition of Baghlan province. 


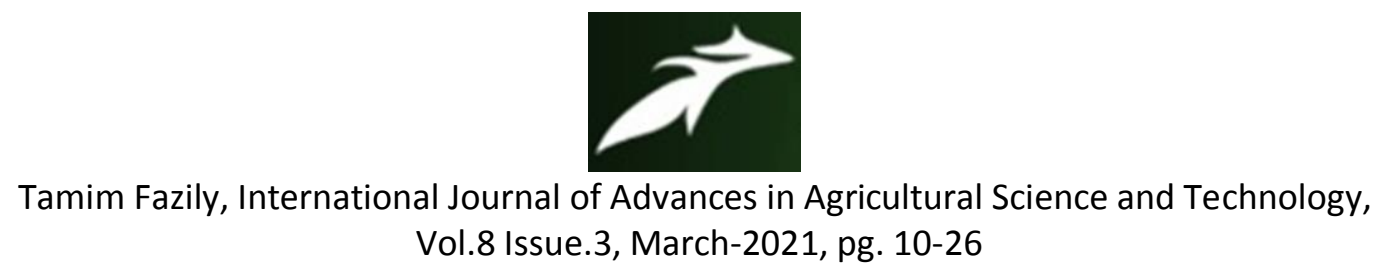

ISSN: 2348-1358

Impact Factor: 6.057

NAAS Rating: 3.77

They found that all varieties sown in 25th November-15 significantly produced higher plant height, number of effective tillers, took more number of days to heading and physiological maturity, higher test weight and grain yield than varieties sown on 26th December and 11th January 2016. Among the varieties Chonta 01, produced significantly higher grain yield but on par with Kabul 013 at all dates of sowing. Habibi et al. (2019) conducted a field experiment on sandy loam soils of Poz-e-Ishan Research Farm of Agricultural Faculty of Baghlan University, to study the response of 11 different wheat varieties to water stress condition of Baghlan province. They observed that among all varieties SHARORA//INQALAB $91 * 2 /$ TUKURU has taken more number of days to $70 \%$ heading (135 days), longer days for $70 \%$ anthesis (141.33) and longer period (165 days) to maturity. Similarly, SHARORA/INQALAB 91*2/TUKURU produced significantly taller plant height (111.33), more number of effective tillers (4.97/ plant) at maturity, longer spike length $(10.50 \mathrm{~cm})$, heavier test weight $(40.24 \mathrm{~g})$ and grain $(4080 \mathrm{~kg} / \mathrm{ha})$ and straw yield $(6587 \mathrm{~kg} / \mathrm{ha})$ over all other treatments. Bachhoa et al. (2018) conducted a field experiment to find the effect of four sowing dates (S1: 3rd week of November, S2: 1st week of December, S3 : 3rd week of December, S4 : 1st week of January) for three wheat varieties of V1 :Trimbak (NIAW 301), V2 : Tapowan (NIAW 917) and V3 : Godavari (NIDW 295). Among sowing dates S2 (1st week of December) was found superior for growth, yield attributes and yield of wheat. Among the wheat varieties Tapowan was found better to sowing date of 1st week of December with regards to growth and yield attributes. Economically Tapowan wheat variety in S2 (1st week of December) sowing date attained higher gross, net monetary returns and B:C 2.02. Lodo et al. (2018) concluded that variety Imdad-2005 was superior in all the growth and yield contributing characters, followed by W.R.I-11 and SKD-2; while among sowing dates, 15th November remained appropriately best sowing time for producing highest grain yield in all varieties respectively.

Yadav et al. (2017) found a significant increase of 5.9 per cent in grain yield of wheat sown at normal date (15th November) than sowing date on 25th November. Hossain et al. (2017) conducted a research experiment to evaluate the performance of three wheat varieties ('Shatabdi', 'BARI Gom 27' and 'BARI Gom 28') at three sowing dates viz., early sowing (1st November), optimum sowing (15th November) and late sowing (30th December). They concluded that 'BARI Gom 28' was the best variety, followed by 'Shatabdi' and 'BARI Gom 27' for producing higher grain yield and November 15th was the best time for sowing of wheat, whereas December 30th was the worst sowing condition that negatively affected on grain yield of wheat. Verma et al. (2016) concluded that the timely sowing (15th November) produced significantly higher grain yield than delayed sowing (25th November). A decreased of $6.3 \%$ in grain yield was recorded by advancing the sowing of wheat crop by 10 days. Kamrozzaman et al. (2016) conducted a field experiment to study the growth and yield performance of cv. BARI Gom-24 as affected by different dates of sowing (November 5, November 15, November 25, December 5 and December 15). The overall results indicated that November 25 sown crop showed better performance in respect of growth and yield of wheat under Charland ecosystem of Bangladesh. Krupnik et al. (2015) reported that early sowing caused wheat to escape heat stress, as the late sowing takes wheat growth into a period during which higher temperatures are experienced, resulting in terminal heat stress and yield loss.

Mumtaz et al. (2015) conducted two years field experiments to find the effect of six different sowing dates (D1-1 November, D2-11 November, D3-21 November, D4-1 December, D5-11 December, D6-21 December) on growth, yield and yield components of six different wheat genotypes (V1-Aari-11, V2-Aas-11, V3-Meraj-08, V4-Millat-11, V5-Punjab-11, V6-Seher-06). Two years results revealed that wheat sown on 11th November performed better with respect to days taken to booting, heading, anthesis, maturity, germination count, number of tillers, plant height, number of grains per spike, test weight and 


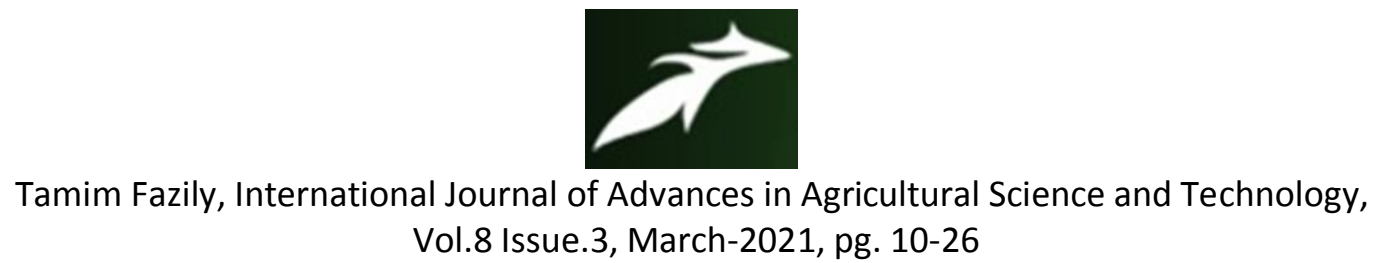

ISSN: 2348-1358

Impact Factor: 6.057

NAAS Rating: 3.77

grain yield. It was also revealed that late sowing of wheat caused reduction in these attributes. Zia ul Hassan et al. (2014) reported that yield of wheat was reduced by 17.4, 17.2 and 26.2 per cent in the crop planted on $15^{\text {th }}$ November, 30th November and 15th October, respectively, as compared with crop planted on 30th October sowing. Tomar et al. (2014) reported that early sowing (14th November) resulted 12.8 per cent higher grain yield than to that of 21 st November sowing. The delayed sowing on $8^{\text {th }}$ December reduced the grain yield by 19.3 per cent than that of 14th November sowing. Suleiman et al. (2014) evaluated four sowing dates of wheat (November 1, November 15, December 1 and December 15) on five wheat varieties at Bahri (Sudan). They observed highest number of tillers, extended phenological parameters and highest grain yield with cultivars which were sown on 1st November followed by 15th November. On overall basis, it was concluded that wheat should be sown from 11th November to 21st November to get high crop yield. Nagarjuna et al. (2014) concluded that date of sowing and variety significantly influenced the yield attributes, yield and economics of wheat. Amrawat et al. (2013) observed that delay in sowing beyond 20th November significantly reduced the grain yield of timely sown wheat varieties. Pal and Murty (2013) reported that higher grain yield of wheat sown on November 20 was due to lower mean minimum and maximum temperature than late planting in Pantnagar of India.

Chourasiya et al. (2013) reported that early sowing (11th November) of HI 8498 wheat variety produced $6.37 \%$ lower grain yield compared to normal date (18th November). Similarly, the grain protein content of early sown varieties was higher compared to normal and delayed sown crop. The highest gross return, net return and benefit:cost of all wheat varieties sown on 18th November was higher than varieties sown on 11th and 25th November. Alam et al. (2013) concluded that November 20 sown crop resulted in significantly higher plant height, dry matter, leaf area index, days taken to maturity and number of tillers than December 20 sown crop. Similarly the crop sown 20th November produced 14.7 per cent higher number of spikes, $26.4 \%, 15.1 \%$ and 45.2 percent higher spike length, number of grains per spike and grain yield as compared to 20th December sowing respectively. Sufyan et al. (2013) conducted a field research at Adaptive Research Farm, Sheikhupura, Punjab, Pakistan to investigate the growth and yield response of three wheat varieties (Inqalab-91, Uqaab-2000 and AS-2002) at two different sowing dates (24.11.03 and S2 = 14.12.03). They found that increase in all yield attributes such as number of effective tillers, spikelets per spike, grains per spike and test weight of wheat was recorded with early November sown crop. The cultivar AS-2002 with the highest grain yield of $3647 \mathrm{~kg} \mathrm{ha}^{-1}$ at early (November) sowing were considered suitable than the rest of two other cultivars. Kumar (2012) recorded highest yield attributes, grain and straw yield of wheat sown on 10th November followed by 17th and 24th November sown crops. Ram et al. (2012) reported that sowing of six varieties of wheat at seven dates of sowing (October 25, November 5, November 15, November 25, December 5, December 15 and December 25) indicated that October 25 took maximum number of days, growing degree days, photo-thermal units and helio-thermal units for earing and maturity resulting to higher grain yield. All these characters were reduced significantly with subsequent delay in sowing time and recorded lowest value in December 25 sown crop. They also stated that early sowing was considered as optimum and timely sown calendar which resulted to better grain development due to longer growing period which had more time for the dry matter accumulation to produce the higher grain yield. Mohsen and Yamada (1991) concluded that low temperature in the growing season reduces germination and retards vegetative growth by inducing metabolic unbalances and can delay or prevent reproductive devolvement of wheat crop. Seleiman et al. (2011) revealed that among different dates of sowing the highest values for all growth, yield and its components as well as grain quality characters was obtained from wheat sown on 15 th November. Pal et al. (2010) evaluated the effect of three wheat genotypes (HUW-234, PBW-373 and UP-2338) on three 


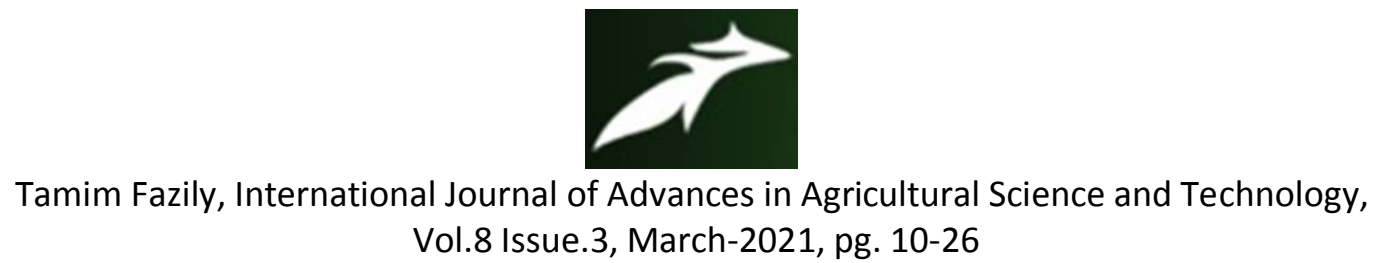

Vol.8 Issue.3, March-2021, pg. 10-26

ISSN: 2348-1358

Impact Factor: 6.057

NAAS Rating: 3.77

dates of sowing (15 December 2005, 25 December 2005 and 4 January 2006). They found that however HUW-234 produced better test weight and more no. of grains/m2 but PBW-373 produced higher grain yield in all dates of sowing. Shirpurkar et al. (2008) observed that early sowing (8th November) of wheat crop produced significantly higher grain yield than late sowing (20th December). Sattar et al. (2010) observed that delayed sowing reduced crop emergence due to poor crop establishment and reduced the number of productive tillers and ultimately the final yield. Dry matter accumulation was reduced with delay in sowing due to high temperature at reproductive stage of the crop which further decreased the final yield.

Jalota et al. (2010) concluded that early sown wheat in November produced the highest grain yield. Tahir et al. (2009) reported that delayed sowing affected germination, growth, grain development and producesd poor tillering due to winter injury in low temperature and suppressed the yield. Normal sowing prolongs the duration of tillering and produces more number of tillers, number of spikes, grains per spike and grain weight that ultimately boosts up grain and straw yields (Qasim et al., 2008). Singh et al. (2008) revealed that delay in sowing beyond 15 November significantly reduced ear length and number of grains per ear during both years. Among the cultivars, the length of spike was highest with PBW-502 which was closely followed by PBW-343. Qasim et al. (2008) evaluated the response of three wheat cultivars (Suliman-96, Chakwal-97 and Inqalab-91) on three sowing dates of sowing (15 November, 30 November and 15 December). They reported that maximum, yield attributes, grain and straw yield of wheat was obtained from early sowing date (15 November). Among varieties Suliman-96 produced higher grain yield at all sowing dates. Tripathi and Verma (2007) observed that delay in sowing from 28 November to 28 December reduced the LAI to $15.02 \%$ at 60 DAS and this reduction increased to $29.39 \%$ at 75 DAS. The significantly lower chlorophyll content at 20 days after anthesis was observed in late-sown crop and in general a decline in leaf greenness was observed from optimum to late sown wheat. Shirpurkar et al. (2007) obtained maximum grain yield of wheat with normal sowing crop (11th November) than late sowing (27th November). Dhaka et al. (2006) found that the delay in wheat sowing time from 20th Nov. to 25th Dec. caused adverse effect on plant growth. The final plant height recorded at maturity was about $10 \mathrm{~cm}$, lower under late sowing than timely sowing. The reduction in plant height under delayed sowing was primarily because of shortening of vegetative phase. During both the consecutive years the final dry weight at maturity was $30.0 \%$ and $26.0 \%$ lower under delayed sowing respectively. Marked reduction in grain yield (49.8 and 48.4 per cent) and straw yield (19.1 and 21.4 per cent) was observed under late sowing during both the consecutive years respectively. Significant reduction in harvest index was also observed apparently because the reductions in grain yield.

Zende et al. (2005) evaluated the effects of sowing time (15th November, 1 st December and 15th December) on the growth and yield of durum wheat cultivars AKDW 4146 and MACS 2846 in Akola, Maharashtra, India. They concluded that both varieties had significantly higher growth and yield components on 15th November compared with those sown on 1st December and 15th December. Mishra et al. (2003) investigated the effect of 2 sowing dates, i.e. 22 November (normal) and 22 December (late), on yield component and yield of 12 wheat genotypes (CPAN-3004, NIAW-34, PBW-343, PBW-373, RAJ-3077, RAJ-3765, UP-2003, UP-2338, UP-2382, UP-2425, WH-542 and WH-896). The normal-sown condition produced significantly higher yield over late-sown condition. Among the varieties PBW-343 produced significantly higher yield components and yield during 2000-01, while the significantly higher yield of wheat among the cultivars during 2000-02 was recorded from UP-2425. The higher yield of early sowing over late sowing wheat can be the result of longer growing period, vigorous growth with rapid 


\section{$\vec{a}$ \\ Tamim Fazily, International Journal of Advances in Agricultural Science and Technology, Vol.8 Issue.3, March-2021, pg. 10-26}

ISSN: 2348-1358

Impact Factor: 6.057

NAAS Rating: 3.77

and uniform seedling emergence resulting higher number of tillers which ultimately contributed to final yield (Munir et al., 2002; Tanveer et al., 2003).

Sardana et al. (2002) reported wheat grain yield reduced to 32.6 per cent with mean reduction of $45 \mathrm{~kg}$ grain/ha/day with delay in sowing from 15th November to 15th December. Singh et al. (2002) observed that the germination percentage, shoot and root length, total seedling length, seedling dry weight, yield components, biological yield, harvest index and seed vigour of wheat decreased with delay in sowing from 1st December to 10th January. Jadhav and Karanjikar (2001) found that the grain yield of late sown wheat was higher than normal sown crops. Among different cultivars Bread wheat genotype DWR 225 produced higher yield. Patil et al. (2001) observed that among six cultivars, AKW-381, produced the highest average number of tillers per plant and total biomass at maturity, suggesting that these cultivars were most beat-resistant, as it exhibited stable biomass production under varying environmental conditions associated with various sowing periods. Donaldson et al. (2001) revealed that early sowing increased the grain and straw yield of wheat of wheat over mid to late sowing date. Ghosh $e t$ al. (2000) concluded that delayed sowing decreased the LAI and dry matter accumulation at all of the growth stages. The highest yield attributes and grain yield of wheat were achieved from 16th November sown crop but were on par with those of the crop raised on 26th November which further the grain yield gradually decreased with delay in sowing. Kumar et al. (2000) observed that wheat sown on 20th November indicated better growth than 1st November or 10th December. The variety cv. WH-542 produced higher yield than HD-2329 and WH-533. Tripathi et al. (2000) tested the effect of sowing dates (30 September, 15 October and 31 October) on wheat cultivars (GW-1034, HI-1277, Sujata and A-9-301) in Madhya Pradesh, India. They found that A-9-30-1 and Sujata produced higher grain and straw yield of wheat. Sowing on 15 October produced higher yield and yield components compared to other sowing dates. Mishra et al. (2000) recommended the DL 788-2 and GW 190 varieties of wheat for normal and late sowing conditions due to their higher adaptability and stability. They found that cultivar WH 147 was responsive on normal sowing dates. Nainwal and Singh (2000) revealed that one month delay in sowing of wheat during winter season of 1995-96 and 1996-97 at GBPUA \& T, Pantnagar with two dates of sowing (27th November and 27th December) significantly reduced the growth characters, growth phenology, yield attributes, grain growth duration, grain and yield of wheat during both the years.

Lathwal et al. (1999) conducted a research experiment to know the response of different wheat cultivars on different dates started from 5-November with 10 days interval to 5-December. They observed that the plant height, grain and straw yield and harvest index of wheat decreased with the every 10 days delay in sowing date. Patel et al. (1999) concluded that the nutrient uptake of wheat varieties was higher on 1st week of December (5th December) as compared to other dates of sowing (25th November,15th and 25th December and 5th January) Tiwari et al. (1999) observed that the wheat crop was sown in the fourth week of November produced significantly highest grain and straw yields than those of other sowing dates. The increased yield at this sowing date may be owing to significantly higher number of tillers/meter row length as well as higher values of other yield attributes. Sowing in fourth week of November also recorded maximum harvest index and significantly highest net return than rest of sowing dates. Early sowing always produces higher yield than late sowing. Each day delay in sowing from 20th November decreased grain yield at $39 \mathrm{~kg} \mathrm{ha}^{-1}$ per day (Singh and Uttam, 1999). Rajput and Verma (1994) revealed that normal sowing produced higher grain yield than late sowing. Jain et al. (1992) studied the impact of 5 sowing dates on six wheat varieties and found that all varieties sown on December 20 produced significantly higher grain yield as compared to other late sowing dates. Too early sowing produces weak plants with poor root systems. Temperature above optimum leads to irregular germination and the embryo 


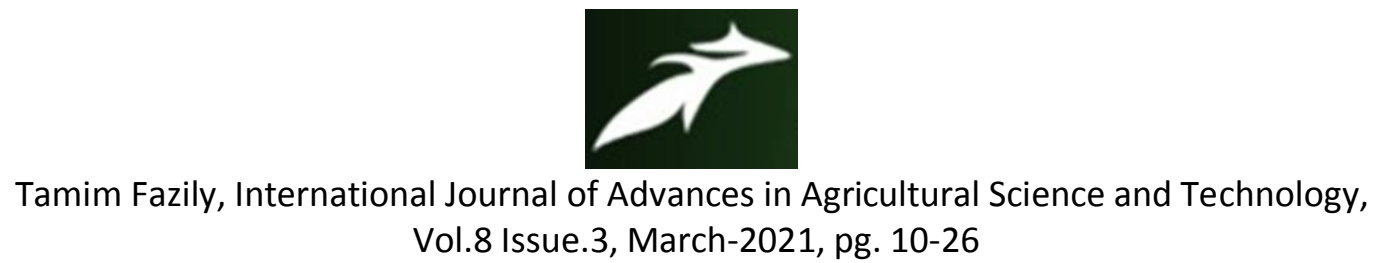

Vol.8 Issue.3, March-2021, pg. 10-26

ISSN: 2348-1358

Impact Factor: 6.057

NAAS Rating: 3.77

frequently dies and the endosperm may undergo decomposition due to activities of bacteria or fungi. In late planting, the wheat variety should be short duration that may escape from high temperature at the grain filling stage (Phadnawis and Saini, 1992). Randhawa et al. (1981) reported that when the crop is sown late, its flowering period is shortened because by the time it comes to flowering, the atmospheric temperature starts rising, therefore, the late sown crop is forced to flower and mature early. Ansary et al. (1989) concluded that delay sowing suppressed the yield, caused by reduction in the yield contributing traits like number of tillers, number of grains per spike and grain yield. Ahmed (1986) observed 1.3\% reductions in one day of December. He concluded that adverse effect of temperature could be minimized by adjusting sowing time to an optimum date and to find out heat tolerant genotypes, which are suitable for late and very early sown conditions to ensure high grain yield. Razzaq et al. (1986) concluded that the emergence and number of days to earing wheat was higher in 15th November and decreased with delay in planting to 15 December. Wiegard and Cellular (1981) reported that increase of each $1.0 \mathrm{oC}$ in mean daily air temperature during grain filling of wheat resulted in decrease of 3 days in grain filling period.

\section{Effect of seed rate and variety on growth and yield of wheat}

Bhatta et al. (2017) evaluated the effects of three seeding rates $(0.5,1$, and 2 times of the normal seeding rate), six genotypes and top dressed nitrogen ( 0 and $34 \mathrm{~kg} \mathrm{~N} \mathrm{ha}-1$ at the flag leaf stage) on yield and agronomic characteristics of winter wheat at two sites (ARF and HPAL sites) for two years. They found that twice, seeding rate increased grain yield, by 5\% in 2014 and 13\% in 2015 at ARF and the yield increase was 9\% in 2014 and 5\% in 2015 at the HPAL site. Instar (2017) evaluated the effect of six seeding rates $\left(80,100,120,140,160\right.$ and $\left.180 \mathrm{~kg} \mathrm{ha}^{-1}\right)$ on growth and yield of three wheat cultivars (Bohooth 22, Bohooth 158, and Rasheed). They reported that plant height increased with increasing seeding rate and $180 \mathrm{~kg} \mathrm{ha}^{-1}$ seed rate produced highest grain yield, where the highest number of tillers, biological yield and straw yield were recorded at $140 \mathrm{~kg} \mathrm{ha}^{-1}$ seeding rate. Increase in seed rate decreased the stem diameter and maximum stem diameter was noted with seeding rate of $80 \mathrm{~kg} \mathrm{ha}^{-1}(4.14 \mathrm{~cm})$. Among the cultivars Rasheed produced highest plant height, stem diameter, more number of tillers and highest biological and straw yield. Yadav and Dhani (2017) concluded that among different doses of nitrogen $(100,120$ and $140 \mathrm{~kg} / \mathrm{ha})$ and 100,125 and $150 \mathrm{~kg} / \mathrm{ha}$ seed rate, application of $140 \mathrm{~kg} \mathrm{~N} / \mathrm{ha}$ and $150 \mathrm{~kg}$ seed rate/ha was the best combination for getting higher seed yield with better quality. Akhtar et al. (2017) conducted a research with three seeding rates $\left(100,120\right.$ and $\left.140 \mathrm{Kg} \mathrm{ha}^{-1}\right)$ and five wheat varieties (BARI Gom 24, BARI Gom 25, BARI Gom 26, BARI Gom 27 and BARI Gom 28) in Bangladesh Agricultural Research Institute, Dinajpur, Bangladesh to determine the optimum seed rate for newly released varieties. They found that performance of yield traits and yield of the wheat varieties varied with seeding rates. They concluded that optimum seed rate for varieties BARI Gom 24, BARI Gom 26 and BARI Gom 28 were $140 \mathrm{~kg}$ seed ha ${ }^{-1}$. Whereas $120 \mathrm{~kg}$ seed ha ${ }^{-1}$ was found to be the optimum seed rate for varieties of BARI Gom 25 and BARI Gom 27.

Anwar et al. (2015) evaluated the effect of seed rates $\left(120,150,180 \mathrm{~kg} \mathrm{ha}^{-1}\right)$ and sowing dates (29th October, 10th November, 24th November, 10th December, 26th December and 10th January) on agro-physiological traits of wheat. They concluded that wheat should preferably be sown between 29th October and 24th November at $150 \mathrm{~kg} \mathrm{ha}^{-1}$ seed rate to get higher grain yield in Peshawar valley. Nizamani et al. (2014) conducted a field experiment to determine the influence of different seed rates $\left(100,125\right.$ and $\left.150 \mathrm{~kg} \mathrm{ha}^{-1}\right)$ on yield contributing traits of promising wheat varieties viz. Sarsabz, Kiran-95 and TD-1. They concluded that the Kiran-95 at seed rate of $125 \mathrm{~kg} \mathrm{ha}^{-1}$ performed best, followed by TD1 and Sarsabz which also produced more yield at seed rate of $125 \mathrm{~kg} \mathrm{ha}^{-1}$. Costa et al. (2013) conducted 


\section{$\vec{a}$ \\ Tamim Fazily, International Journal of Advances in Agricultural Science and Technology, Vol.8 Issue.3, March-2021, pg. 10-26}

ISSN: 2348-1358

Impact Factor: 6.057

NAAS Rating: 3.77

an experiment to determine the effect of sowing date and seeding rate (200 and 350 seeds $\mathrm{m}^{-2}$ ) on test weight and grain yield of fifteen bread wheat varieties and five advanced lines from Portuguese Wheat Breeding Program under irrigated Mediterranean systems. They found that sowing date and seeding rate affected test weight and yield under irrigated field conditions. Higher yield of wheat was obtained with the 2 nd sowing date (21 December) for most of the varieties. Laghari et al. (2011) evaluated the effect of different seed rates $\left(125,150,175\right.$ and $\left.200 \mathrm{~kg} \mathrm{ha}^{-1}\right)$ on growth, yield and nutrient uptake of wheat varieties (TD-1, TJ-83 and Mehran-89). They observed that wheat crop sown at low seed rate of $125 \mathrm{~kg}$ $\mathrm{ha}^{-1}$ had better growth, yield, nutrient uptake and low lodging tendency. The variety TD-1 sown at $125 \mathrm{~kg}$ $\mathrm{ha}^{-1}$ produced maximum tillers, spike length, grains per spike, grain weight per spike, dry matter, crop growth rate, seed index, biological yield, grain yield, harvest index and low lodging. However, higher seed rates $\left(200 \mathrm{~kg} \mathrm{ha}^{-1}\right)$ resulted in delayed maturity, greater internodes length and higher lodging in Mehran-89. They also concluded that optimum seeding rate is one of the important management factors for achieving higher yield of wheat since it is under the control of farmers in many cropping systems. Ram et al. (2013) investigated influence of varieties (PBW 550, PBW 343 and DBW 17) and seeding rates $(87.5,100,112.5$ and 125) on growth, productivity, disease reaction and economics of wheat at Ludhiana, India in 2007-08 to 2008-09. They found that there was no trend for different diseases with respect to seed rate. The highest productivity was recorded in $112.5 \mathrm{~kg}$ seed rate/ha which was significantly higher than all the other seed rates. The highest grain yield of PBW 550 at seed rate of 112.5 $\mathrm{kg} / \mathrm{ha}$ was statistically on par with only PBW 550 at $125 \mathrm{~kg}$ seed rate ha ${ }^{-1}$ but significantly higher than all the other varieties at all the seed rates. The highest gross, net returns and B:C recorded in PBW 550 at $112.5 \mathrm{~kg}$ seed rate ha ${ }^{-1}$.

Ram et al. (2012) reported that among six varieties of wheat sown at seven dates of sowing (October 25, November 5, November 15, November 25, December 5, December 15 and December 25) October 25 took maximum number of days, growing degree days, photo-thermal units and helio-thermal units for earing and maturity which resulted to highest grain yield. Further all these parameters significantly decreased with subsequent delay in sowing time and the lowest values recorded with December 25 sown crop. They also stated that early sowing was considered as optimum and timely sown calendar which resulted to better grain development due to longer growing period which had more time for the dry matter accumulation to produce higher grain yield. Iqbal et al. (2012) conducted an experiment with three seeding rates of 125,150 and $175 \mathrm{~kg} /$ ha with five nitrogen levels of $0,75,100,125$ and $150 \mathrm{~kg}$ $\mathrm{N} / \mathrm{ha}$. They found significant interaction for number of grain/ spike, grain yield, biological yield and harvest index and were maximum at seeding rate of $150 \mathrm{~kg} / \mathrm{ha}$ with nitrogen level of $125 \mathrm{~kg} / \mathrm{ha}$. McKenzie et al. (2011) reported that increase in seed rate results to higher plant population thus suppress weeds and will give maximum yield and economic returns. Akmal et al. (2011) reported that each week delay in date of wheat sowing reduces the yield through shortening of vegetative and reproductive stages and overall the crop duration. Ali et al. (2010) evaluated the impact of four levels of seeding rates (125, 150,175 and $200 \mathrm{~kg} \mathrm{ha}^{-1}$ ) for three consecutive seasons. They found that increase in seeding rate up to $200 \mathrm{~kg} \mathrm{ha}^{-1}$ increased the straw yield of wheat while the lowest straw yield of wheat was obtained with seeding rate of $125 \mathrm{~kg} \mathrm{ha}^{-1}$ during entire three consecutive seasons.

Malik et al. (2009) concluded that the germination, yield attributes and yield of wheat was decreased with delayed in date of sowing whereas the increase in seeding rate did not affect grain yield. Kabir (2009) concluded that that the seed rate of $140 \mathrm{~kg} \mathrm{ha}^{-1}$ with one irrigation given at CRI stage may be practiced for better performance of wheat cv. Early crop establishment is a key factor for higher wheat production (Soomro et al., 2009). Dubey et al. (2008) reported that date of sowing significantly 


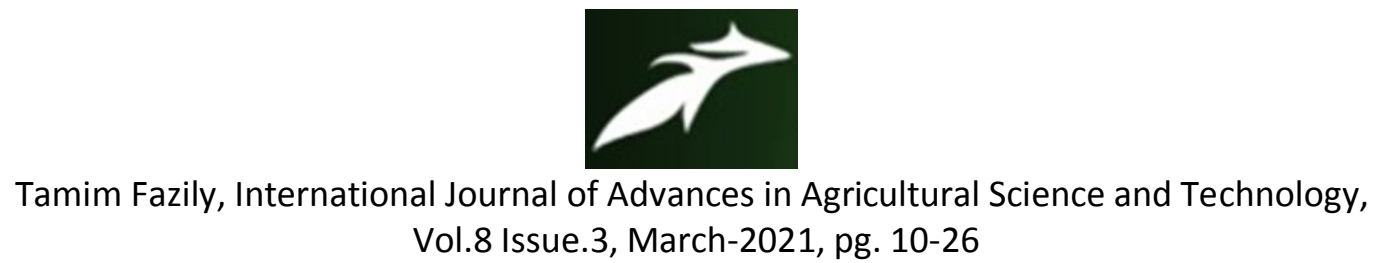

ISSN: 2348-1358

Impact Factor: 6.057

NAAS Rating: 3.77

influenced the yield of wheat. The highest grain yield of wheat was produced on 30 November sowing date. One month delay in sowing (30 November-30 December) reduced the grain yield by $20 \%$. Bakht et al. (2007) studied the response of four wheat varieties (Fakhr-e-Sarhad, Suleman 96, Haider 2000, Saleem 2000 and Khyber 87) to four rows spacing $(30,40,50$ and $60 \mathrm{~cm})$. They recorded maximum grain yield $\left(3528 \mathrm{~kg} \mathrm{ha}^{-1}\right.$ ), number of grains per spike (68) and test weight (45 g) of all varieties with row spacing of $30 \mathrm{~cm}$. while the minimum grain yield $\left(1891 \mathrm{~kg} \mathrm{ha}^{-1}\right)$ was recorded in $60 \mathrm{~cm}$ row spacing. Hiltbrunner et al. (2007) stated that increase in seeding density and sowing time is an effective mean to increase the grain yield. Ozturk et al. (2006) stated the decrease in seed rate from 625 to 325 seeds $\mathrm{m}^{-2}$ increased the number of kernels per spike. They concluded that stated that seeding rate directly influences the number of spikes per unit area, which further increase other yield components such as the number of grains per spike and individual grain weight. Kristo et al. (2006) reported that the growth and yield of winter wheat was higher under more favorable conditions (October sowing) with seeding rate of 600 seeds $\mathrm{m}^{-2}$ than those grown under unfavourable conditions (November sowing) with seeding rate of 300 seeds $\mathrm{m}^{-2}$. Khan et al. (2005) concluded that among seeding rate of $(100,120,140$ and $160 \mathrm{~kg} / \mathrm{ha})$ of wheat sowing rates of 100 and $120 \mathrm{~kg} / \mathrm{ha}$ produced significantly higher spike length, number of grains per spike, number of spikelets per spike and ultimately higher grain and straw yield. Whereas lowest yield traits and yield was obtained from sowing rates of 140 and $160 \mathrm{~kg} \mathrm{ha}^{-1}$.

Wajid et al. (2004) conducted a research experiment to investigate the effect of sowing date (10 November, 25 November and 10 December) and plant population (200-, 300- and 400 plants $\mathrm{m}^{-2}$ ) on biomass, yield components and grain yield of wheat. The early sowing (10 Nov.) produced $60.6 \%$ higher grain yield over late sowing (10 Dec.). While the grain yield of 10 Nov. sowing was $45 \%$ higher than 25 Dec. sowing. Increasing plant population from 200 plant $\mathrm{m}^{-2}$ to $300-$ and 400 plant $\mathrm{m}^{-2}$ also enhanced grain yield but the response was quadratic. Lloveras et al. (2004) reported that due to differences in environmental factors, soil type, sowing date and wheat genotypes the appropriate seeding rate significantly differs from region to region. Staggenborg et al. (2003) reported that reduced tiller formation of wheat can be compensated by higher seeding rate through production of more main stem spikes particularly for the crop genotypes which produces less number of tillers. Kumar et al. (2002) reported that net return increased with increasing seed rates and the benefit cost ratio was highest with $100 \mathrm{~kg} / \mathrm{ha}$ sowing rate. High or low seeding rates reduce the chances of obtaining full yield potential of specific genotype. Grain yield followed a positive linear response (Geleta et al., 2002). Spink et al. (2000) stated that lower seeding rate may increase the risks for reducing yield, whereas higher seeding rate may increase overall cost of production. Khan et al. (2002) reported that seeding rate of $150 \mathrm{~kg} / \mathrm{ha}$ had higher emergence, plant height, number of effective tillers and grain yield. Seeding rate of $100 \mathrm{~kg} / \mathrm{ha}$ took maximum number of days to maturity, while $50 \mathrm{~kg}$ seeded rate produced more number of grains/spike and test weight.

\section{Conclusion}

Optimum seed rates date of sowing and suitable cultivars play an important role in achieving potential yield of wheat. Plant density is a major factor determining the ability of the crop to capture resources and generate yield. It can be developed by using a suitable seeding rate to produce higher grain yield of wheat. The seed rate increases with delay in sowing due to poor plant stand, where higher seed rate produces more plants in unit area resulting in higher intra-crop competition hereby affecting the yield and production cost. Similarly lower plant population produces lower grain yield due to higher vegetative growth and space wastages. Growth and yield of wheat are affected by environmental conditions which 


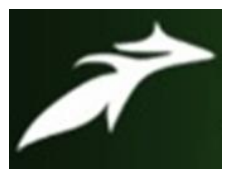

Tamim Fazily, International Journal of Advances in Agricultural Science and Technology,

Vol.8 Issue.3, March-2021, pg. 10-26

ISSN: 2348-1358

Impact Factor: 6.057

NAAS Rating: 3.77

can be regulated by sowing time, seeding rate and variety which are under the control of farmers in most cropping systems especially in wheat cultivation. However high yielding wheat varieties have maximum genetic potential to produce high yield but they cannot explore their genetic potential without ensuring proper time of sowing and seeding rate. Consequently, there is a relationship between cultivar, plant density and sowing date. As the plant density increases, the competition for resources especially for water, nutrient and space also increases that badly affect the final yield. Similarly different high yielding cultivars have varied optimum seed rate to maintain the optimum plant population for higher yield. Too early sowing when temperature is above the optimum produce poor plants and even higher seeding rate cannot compensate low yield. Under late sown conditions, wheat faces low temperature in the earlier stage and high temperature in the later stages of the growing season which due to lack of favorable moisture for its better growth and development at this stage causes yield reduction. At optimum temperature, early sowing with optimum plant population enhances the growth and nutrient uptake and causes higher crop production. Therefore to minimize the effect of temperature variation caused due to changed sowing date by choosing appropriate wheat varieties with the optimum seed rate which can synchronize its temperature requirement and to produce optimum yield, proper sowing date, optimum plant population and varietal selection according to environmental conditions are the best noncash options to increase growth, yield and quality traits of the wheat.

\section{References}

[1]. Ahmed SM (1986). An overview of wheat research and development in Bangladesh. 3rd National Wheat Training Workshop. August 4-5, 1986. Wheat Res. Cent., Bangladesh Agril. Res.Inst.,Dinajpur.

[2]. Akhtera Mst. Masuma, Sabaghb Ayman EL, Alama Md. Nur, Hasand Md. Kamrul, Emad Hafezb, Barutçularc Celaleddin, Islamd Mohammad Sohidul (2017). Determination of seed rate of wheat (Triticum aestivum L.) varieties with varying seed size. Scientific Journal of Crop Science. 6(3) 161-167.

[3]. Akmal, M. S.M. Shah, M. Asim and M. Arif. (2011). Causes of yield reduction by delayed planting of hexaploid wheat in Pakistan. Pak. J. Bot., 43(5): 2561-2568.

[4]. Alam, M.P., Kumar, S., Ali, N., Manjhi, R.P., Kumari, N., Lakra, R.K. and Izhar, T. 2013. Performance of wheat varieties under different sowing dates in Jharkhand. Journal of Wheat Research 5(2): 61-64.

[5]. Ali, M.A., Ali, M., Sattar, M. and Ali, L. (2010). Sowing date effect on yield of different wheat varieties. Journal of Agricultural Research 48(2): 157-162.

[6]. Altenbach, S. B. - DuPont, F. M. - Kothari, K. M. - Chan, R. - Johnson, E. L. - Lieu, D.(2003). Temperature, water and fertilizer influence the timing of key events during grain development in a US spring wheat. Journal of Cereal Science, 37: 9-20.

[7]. Amrawat, T., Solanki, N.S., Sharma, S.K., Jajoria, D.K. and Dotaniya, M.L. (2013). Phenology, growth and yield of wheat in relation to agrometeorological indices under different sowing dates. African Journal of Agricultural Research 8(49): 6366-6374. 


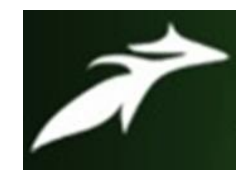

Tamim Fazily, International Journal of Advances in Agricultural Science and Technology, Vol.8 Issue.3, March-2021, pg. 10-26

ISSN: 2348-1358

Impact Factor: 6.057

NAAS Rating: 3.77

[8]. Anwar Shazma, Khattak Wajid Ali, Inamullah, Islam Muhammad, Bashir Saqib Shafi Muhammad and Jehan Bakht. (2015). Effect of Sowing Dates and Seed Rates on the AgroPhysiological Traits of Wheat. Journal of Environment and Earth Science. 5(1): 135-141.

[9]. Ansary, A.H., Khushak, A.M., Sethar, M.A., Ariam, N.A. and Emon, M.Y.M. (1989). Effect of sowing dates on growth and yield of wheat cultivars. Pakistan Journal of Scientific and Industrial Research 32: 39-42.

[10]. Ayaz, S., P. Shah and M. Ali. 1997. Influence of seeding density and geometry of planting on emergence, tillering and biological yield of wheat. Sarhad J. Agric. $13: 219-222$.

[11].Bachhao, K.S., Kolekar, P.T., Nawale, S.S. and Kadlag, A.D.(2018). Response of different wheat varieties to different sowing dates. Journal of Pharmacognosy and Phytochemistry. 7: 2178-2180.

[12]. Beuerlein, J.E. and H.N. Lafever. (1989). Yield of soft red winter wheat as affected by row spacing and seeding rate. Appld. Agric. Res. 4:47-50.

[13]. Bhatta, M., Regassa, T., Rose, D. J., Baenziger, P. S., Eskridge, K. M., Santra, D. K., \& Poudel, R. (2017). Genotype, environment, seeding rate, and top-dressed nitrogen effects on end-use quality of modern Nebraska winter wheat. Journal of the Science of Food and Agriculture, 97(15), 5311-5318.

[14]. Costa Rita , Pinheiro Nuno, Almeida Ana Sofia, Gomes Conceição, José Coutinho, Coco Joã o, Costa Armindo and Maçã s Benvindo (2013). Effect of sowing date and seeding rate on bread wheat yield and test weight under Mediterranean conditions. Emir. J. Food Agric. 2013. 25 (12): 951-961.

[15]. Coventry, D.R., T.G. Reeves, H.D. Brooke and D.K. Cann. (1993). Influence of genotype, sowing date, and seeding rate on wheat development and yield. Aust. J. Exp. Agric. 33:751-757.

[16]. Darwinkel, A., B.A. Hag and J. Kuizenga. (1977). Effect of sowing date and seed rate on crop development and grain production of winter wheat. Netherlands J. Agric. Sci. 24:83-94.

[17]. Dhaka, A.K., Bangarwa, A.S., Pannu, R.K., Malik, R.K. and Garg, R. (2006). Phenological development, yield and yield attributes of different wheat genotypes as influenced by sowing time and irrigation levels. Agricultural Science Digest 26(3): 174-177.

[18]. Donaldson, E., F.W. Schillinger and S.M., Dofing (2001). Straw production and grain yield relationships in winter wheat. Crop Science, 41: 100-106.

[19]. Dubey, A. P., Singh, C. B., Khan, N., Yadav, P. N. and Tiwari, A. N. (2008). Influence of weather parameters on wheat yield under varying sowing dates. Journal of Agrometeorology: 4(5): :74-77.

[20]. Fazily Tamim and Habibi Ainullah (2019). Performance of wheat varieties under different dates of sowing under irrigated condition of Baghlan province, Afghanistan. International Journal of Emerging Technologies and Innovative Research. 6:50-53.

[21]. Geleta, B., M. Atak, P.S. Baenziger, L.A. Nelson, D.D. Baltenesperger, K.M. Eskridge et al.(2002). Seeding rate and genotype effect on agronomic performance and end-use quality of winter wheat. Crop Sci. 42:827-832. doi:10.2135/cropsci2002.0827.

[22]. Ghosh, D.C., Nandi, P. and De, B. (2000). Phenological development and productivity of wheat (Triticum aestivum) at different dates of sowing. Indian J. Agric. Sci. 70(6) : 393-5.

[23]. Habibi Ainullah, Fazily Tamim and Halimi Abdul Hasib (2019). Varietal response of wheat to water stress condition of Baghlan province, Afghanistan. SSRG International Journal of Agriculture and Environmental Science. 6(3): 43-46. 


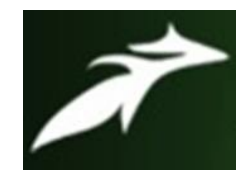

Tamim Fazily, International Journal of Advances in Agricultural Science and Technology, Vol.8 Issue.3, March-2021, pg. 10-26

ISSN: 2348-1358

Impact Factor: 6.057

NAAS Rating: 3.77

[24]. Harrison, K.S. and J.E. Beuerlein. (1989). Effect of herbicide mixtures and seeding rate on soft red winter wheat (Triticum aestivum) yield. Weed Technol. 3:505-508.

[25]. Hossain A, Islam MR, Rahman KAMM, Rashid MH and Anwari A. (2017). Comparative performance of three wheat (Triticum aestivum L.) varieties under heat stress. International Journal of Natural and Social Sciences, 4(3): 26-42.

[26]. Intsar H.H. Al-Hilfy and S.A.Wahid. (2017). Seeding rates influence on growth and straw yield of some bread wheat cultivars and their relationship with accumulated heat units. AmericanEurasian Journal of Sustainable Agriculture. 11(5): 49-58.

[27]. Iqbal, J., K. Hayat, S. Hussain, A. Ali, M.A. Alias and H.A. Bakhsh. (2012). Effect of seeding rates and nitrogen levels on yield and yield components of wheat. Pak. J. Nutr. 11(7): 531-536.

[28]. Jadhav AG and Karanjikar PN (2001). Response of new wheat genotypes to different dates of sowing under irrigated conditions. Annals of Agricultural Research, 22(2): 295-296.

[29]. Jalota, S.K., G.B.S. Singh, S.S. Chahal, S. Ray, P. Bhupinder-Singh and K.B. Singh,( 2010). Soil texture, climate and management effects on plant growth, grain yield and water use by rainfed maize-wheat cropping system: Field and simulation study. Agric. Water Management, 97(1): 8390.

[30]. Kabir, N.A.M.E., A.R. Khan, M.A. Islam and M.R. Haque, (2009). Effect of seed rate andirrigation level on the performance of wheat cv. Gourab. J. Bangladesh Agril. Univ.,7(1): 4752.

[31]. Kamrozzaman M. M. , Khan M. A. H. , Ahmed S. and Sultana N. (2016). Growth and yield of wheat at different dates of sowing under chrland ecosystem of Bangladesh. J. Bangladesh Agril. Univ. 14(2): 147-154.

[32]. Khan, M .A., Marwat K.B. and Gui-Hassan (2005). Wheat yield components as affected due to seed rate and Holy thistle (Silybum marianum Gaertn.) density. Pakistan Journal of Weed Science Research. 11 (3/4): 91-96.

[33]. Khan, Ijaz Ahamd; Bakht, Jehan; Shah, Wajid Ali; Khan, Naeem and Ullah, Ihsan (2002). Effect of Seed Rate on the Yield and Yield Components of Wheat under Irrigated Conditions of Peshawar. Asian Journal of Plant Sciences, 1: 513-515.

[34]. Kristo, I., M. H. Szel, J. Gyapjas and A. Szekeres (2006). Effect of sowing date and seeding rate on different winter wheat cultivars. Available online at http://agricultura.usab-tm.ro/Simpo 2007 pdf/

[35]. Krupnik T J, Ahmed Z U, Timsina J, Shahjahan M, Kurishi A S M A, Miah A A, Rahman B M S, Gathala M K and McDonald A.J. (2015). Forgoing the fallow in Bangladeshes stress-prone coastal deltaic environments: Effect of sowing date, nitrogen, and variety on wheat yield in farmers fields. Field Crops Res 170:7-20.

[36]. Kumar R., Agarwal S.K., and Nanwal R.K, (2002). Economics of bread wheat as affected by planting system, seed rate and nitrogen fertilization in sandy loam soils of Haryana. Haryan Agricultural University Journal of Research. 32(1 ): 23-25.

[37]. Kumar, V. (2012). Effect of dates of sowing on growth and yield of wheat (Triticum aestivum L.) varieties. Thesis, M.Sc. (Agronomy), Department of Agronomy, Institute of Agricultural Sciences, Banaras Hindu University, Varanasi.

[38]. Kumar S, Bangarwa AS and Kadian VS, (2000). Response of wheat varieties to sowing dates and nitrogen level. Ann. Agric. Bio. Res. 5: 99-103. 


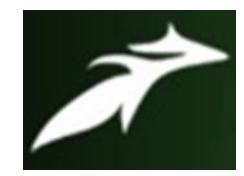

Tamim Fazily, International Journal of Advances in Agricultural Science and Technology, Vol.8 Issue.3, March-2021, pg. 10-26

ISSN: 2348-1358

Impact Factor: 6.057

NAAS Rating: 3.77

[39]. Lathwal OP and Thakral SK, (1999). Performance of wheat varieties sown on different dates under rainfed conditions. Crop Res. Hisar. 18: 470-471.

[40]. Laghari GM, Oad FC, Tunio S, Chachar Q, Ghandahi AW, Siddiqui MH, Hassan SW and Ali A (2011). Growth and yield attributes of wheat at different seed rates. Sarhad Journal of Agriculture. 27(2): 177-183.

[41]. Lloveras, J., J. Manent, J. Viudas, A. Ló pez and P. Santiveri. (2004). Seeding rate influence on yield and yield components of irrigated winter wheat in a mediterranean climate. Agron. J. 96:1258-1265.

[42]. Lodo Sadam Hussain, Shah Pir Syed Naqi Ahmed, Muharam Ali Hisbani, Arsalan Arif Mihas, Aftab Ahmed, Maqsood Ahmed Chandio, Saifullah Kumbhar (2018). Effect of different sowing dates on growth and yield of candidate wheat varieties. National Journal of Advanced Research. 4(1): 41-46.

[43]. Malik, A.U., M.A. Alias, H.A. Bukhsh and I. Hussain. (2009). Effect of seed rates sown on different dates on wheat under agro-ecological conditions of Dera Ghazi Khan. J. Ani. \& Pl. Sci. 19(3): 126-129.

[44]. McKenzie, R.H., E. Bremer, A.B. Middleton, P.G. Pfiffner and S.A. Woods. (2011). Effect of seeding date and rate for irrigated grain and oilseed crops in southern Alberta. Can. J. Pl. Sci. 91: 293-303.

[45]. Mishra, V., Mishra, R.D., Singh, M. and Verma, R.S. (2003). Dry-matter accumulation at preand post-anthesis and yield of wheat (Triticum aestivum) as affected by temperature stress and genotypes. Indian Journal of Agronomy 48(4): 277- 281.

[46]. Mishra , O.K., Khan , R.A. and Baghel , M.S. (2000) . Stability of wheat varieties under various dates of sowing. Annals Agril. Res. 21 (4) : 564-566.

[47]. Mohsen B, Yamada T (1991). Screening spring wheat genotypes (Triticum sp.) for seedling emergence under optimal and suboptimal temperature conditions, Japan J Breed. 41:381- 387.

[48]. Mumtaz, M.Z., Ahmad, M., Aslam, M., Zamil, M., Zaman, M.F., Nasrullah, H.M., Akhtar, M. and Ali, B. 2015. Evaluation of growth and yield attributes of different wheat genotypes sown under various planting times. Journal of Biology, Agriculture and Healthcare 5(19): 85-90.

[49]. Munir AT, Rahman A, Tawaha M. (2002). Impact of seeding rate, seeding date, rate and method of phosphorus application in faba bean (Vicia faba L.) in the absence of moisture stress. Biotechnol, Agron. Soc. Environ. 6(3):171-178.

[50]. Naeem M, (2001). Growth, radiation use efficiency and yield of new wheat cultivars under variable nitrogen rates. M. Sc. Thesis, Dept. Agron, Univ. Agric., Faisalabad.

[51]. Nainwal, K. and Singh, M. (2000). Varietal behaviour of wheat (Triticum aestivum) to dates of sowing under Tarai region of Uttar Pradesh. Indian Journal of Agronomy 45(1): 107113.Nagarjuna et al. (2014)

[52]. Nizamani, G.S., S. Tunio, U.A. Buriro, M.I. Keerio, (2014). Influence of different seed rates on yield contributing traits in wheat varieties. J. plant Sci., 2(5): 232-236.

[53]. Osmani Mohammad Hakim, Fazily Tamim, Koshani Beheshtah and Mirzaee Mujtaba (2020). Comparison of adaptation assessment of four local spring varieties in Kabul climatic condition. EPRA International Journal of Research and Development. 5(1):21-23.

[54]. Ozturk, A., O. Caglar and S. Bulut. (2006). Growth and yield response of facultative wheat to winter sowing, freezing sowing and spring sowing at different seeding rates. J. Agron. Crop Sci. 192:10-16. 


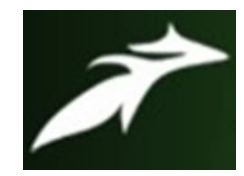

Tamim Fazily, International Journal of Advances in Agricultural Science and Technology, Vol.8 Issue.3, March-2021, pg. 10-26

ISSN: 2348-1358

Impact Factor: 6.057

NAAS Rating: 3.77

[55]. Pal R K and Murty S N (2013). Temperature effect on growth parameters of wheat (cv. PBW343) using Ceres-wheat model for different sowing dates in foot hills of western Himalayas. Indian J Agric Res 47:78-82.

[56]. Patel, S.R., Thakur, D.S. and Lal Nageshwar Lal (1999). Yield and nutrient uptake of wheat (Triticum aestivum) varieties under different sowing II dates. Indian J. Agron. 44 (4) : 733-737 .Piper, C.S. (1950) . Soil and plant analysis. Adelaide University of Adelaide. 223-27 and 77-9.

[57]. Patil, K.S., Durge, D.V ., Phadnawis , B.N., Shivankar, R.S. and Rathod , T.H. (2001). Effect of sowing dates on biomass production of wheat cultivar Annals Pl. Physio. 14 (2): 115-119.

[58]. Phadnawis, B.N. and A.D. Saini. (1992). Yield models 19. Ishag, H.M., (1994). Genotype Differences in heatin wheat based on sowing time and phenological stressed wheat in the irrigated Gezira Scheme. In: developments. Ann. Pl. Physio., 6: 52-59.

[59]. Qasim, M., Qamer, M., Faridullah and Alam, M. 2008. Sowing dates effect on yield and yield components of different wheat varieties. Journal of Agricultural Research 46(2): 135-140.

[60]. Ram H, Buttar G S, Bhagat I, Sharma I, Mavi G S and Jindal M M (2013) Influence of varieties and seeding rates on growth, productivity, disease reaction and economics of wheat in northwest India. J Agric Sci 8:122-35.

[61]. Ram, H., Singh, G., Mavi, G.S. and Sohu, V.S. (2012). Accumulated heat unit requirement and yield of irrigated wheat (Triticum aestivum L.) varieties under different crop growing environment in central Punjab. Journal of Agrometeorology 14(2): 147-153.

[62]. Randhawa, A.S., Dhillon, S.S. and Singh, D. (1981). Productivity of wheat varieties as influenced by the time of sowing. Journal of Research, Punjab Agricultural University 18(3): 227-233.

[63]. Razzaq AP, Zada K and Saeed K, (1986). Effect of sowing dates on emergence, growth rate and days to earing of wheat (Triticum aestivum L.) varieties. Sarhad J. Agric. 2: 3-28.

[64]. Sardana, Virender, Sharma, S.K. and Randhawa, A.S. (2002) . Performance of wheat (Triticum aestivum) varieties under different sowing dates and nitrogen levels in the sub-montane region of Punjab. Indian J. Agron.47 (3) : 372-377.

[65]. Sattar, A., Cheema, M.A., Farooq, M., Wahid, M.A., Wahid, A. and Babar, B.H. (2010). Evaluating the performance of wheat cultivars under late sown conditions. International Journal of Agriculture and Biology 12(4): 561-565.

[66]. Seleiman, M., M. Ibrahiml, S. Abdel-Aal and G. Zahran, (2011). Effect of sowing dates on productivity, technological and rheological characteristics of bread wheat. J. Agron. Crop Sci., 2(1): $1-6$.

[67]. Shirpurkar, G.N., Kashid, N.V. and Pisal, A.A. (2007). Effect of different sowing dates and varieties on yield and yield attributes of wheat. Agricultural Science Digest 27(1): 68-70.

[68]. Shirpurkar, G.N., Wagh, M.P. and Patil, D.T. (2008). Comparative performance of wheat genotypes under different sowing dates. Agricultural Science Digest 28(3): 231-232.

[69]. Singh, C.B., Kumar, J., Khan , A.A., Katiyar, R.A. and Katiyar, A.K. (2002). Effect of nitrogen levels and dates of sowing on yield and qual ity of wheat (Triticum aestivum L.) seeds . Prog. Agric. 2(1): 92-93

[70]. Singh VPN and Uttam SK (1999). Influence ofsowing dates on yield of wheat cultivarsunder saline sodic conditions in Central Utter Pradesh. Indian Journal of Agriculture. 38(1): 64-68.

[71]. Slafer, G.A. and E.H Satorre. (1999). An introduction to the physiological-ecological analysis of wheat yield. In: Wheat: Ecology and Physiology of Yield Determination. Satorre, E.H. and G.A. Slafer (Eds.). The Haworth Press, New York. pp.3-12. 


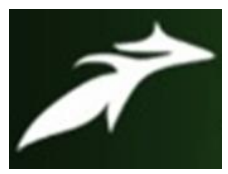

Tamim Fazily, International Journal of Advances in Agricultural Science and Technology, Vol.8 Issue.3, March-2021, pg. 10-26

ISSN: 2348-1358

Impact Factor: 6.057

NAAS Rating: 3.77

[72]. Soomro. Ali Umed, Rahman Ur Mujeeb, Odhano Ali Ejaz. Cunl Sheren and Tahreen Qadir Abdul (2009). Effect of sowing method and seed rate on growth and yield of wheat (Triticum aestivum). World Journal of Agricultural Sciences, 5 (2): 159 -162.

[73]. Spink, J.H., Kirby, E.J.M., Forest, D.L., Bradley, R.S., Scott, R.K., Foukeees, M.J., Clare, R.W. and Evans, E.J. (2000). Agronomic implications of variation in wheat development due to variety, sowing, site and season. Plant, Variety and Seed 13: 91-105.

[74]. Staggenborg, S.A., D.A. Whitney, D.L. Fjell and J.P. Shroyer. (2003). Seeding and nitrogen rates required to optimize winter wheat yields following grain sorghum and soybean. Agron. J. 95:253-259.

[75]. Sufyan, M.A., Mahmood, A., Ali, A., Maqbool, M.M. and Ahmad, M. 2013. Comparative assessment of wheat cultivars and sowing dates under agro-climate of Sheikhupura, Pakistan. Asian Journal of Agriculture and Biology 1(3): 100-104.

[76]. Suleiman A. A., Nganya J. F., and Ashraf M. A. (2014). Effect of Cultivar and Sowing Date on Growth and Yield of Wheat (Triticum aestivum L.) in Khartoum, Sudan. Journal of Forest Products \& Industries. 3(4): 198-203.

[77]. Tahir, M., Ali, A., Nadeem, M.M., Hussain, A. and Khalid, F. (2009). Effect of different sowing dates on growth and yield of wheat (Triticum aestivum L.) varieties in district Jhang, Pakistan. Pakistan Journal of Life and Social Sciences 7(1): 66-69.

[78]. Tanveer SK, Hussain I, Sohail M, Kissana NS, Abbas SG. (2003). Effect of different planting methods on yield and yield components of wheat. Asian J. Plant Sci. 2:811-813.

[79]. Tiwari , P.N., Sharma, Rakesh , K. and Devkant (1999). Impact of improved agro-techniques on wheat (Triticum aestivum). Indian J. Agron. 44( 4 ): 750-753.

[80]. Tripathi Neeta and Verma, R. S. (2007). Influence of late planting on physiological parameters in wheat (Triticum aestivum L.) varieties. Pantnagar Journal of Research. 5 (1) : 6-8

[81]. Tomar, S.P.S., Tomar, S.S. and Srivastava, S.C. (2014). Yield and yield component response of wheat (Triticum aestivum L) genotypes to different sowing dates in Gird region of Madhya Pradesh. International Journal of Farm Sciences 4(2): 1-6.

[82]. Tripathi, M.L., Kurmvanshi, S.M. and Kushwaha, H.S. (2000). Relative performance of rainfed wheat (Triticum aestivum L.) varieties under different dates of sowing in Vindhya Plateau of Madhya Pradesh. Agril. Sci. Digest. 20 (3): 199-200.

[83]. Verma, D.K., Verma, S., Giri, S.P., Pandey, M.K. and Pandey, A. (2016). Response of newly released wheat (Triticum aestivum L.) varieties to different sowing dates under changing climate condition in eastern Uttar Pradesh. International Journal of Agricultural Sciences 12(2):199-202.

[84]. Wajid, S.A. (2004). Modeling development, growth and yield of wheat under different sowing dates, plant populations and irrigation levels. Department of Agronomy, University of Arid Agriculture, Rawalpindi.

[85]. Wardlaw, I. F. - Moncur, L.: 1995. The response of wheat to high temperature following anthesis. I. The rate and duration of kernel filling. Australian Journal of Plant Physiolog. 22: 391-397.

[86]. Weigard, C. E. and Cucellar, J.A. (1981 ). Duration of grain filling and kernel weight of wheat as affected by temperature . Crop Sci. 21: 95-101.

[87]. Yadav, V., Mishra, D.N., Chauhan, R.S., Tomar, P. and Singh, R. (2017). Performance of newly released wheat (Triticum aestivum L.) varieties on different sowing dates under NWPZ of U.P. Journal of Pharmacognosy and Phytochemistry 6(1): 720-722. 


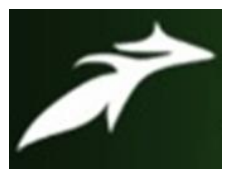

Tamim Fazily, International Journal of Advances in Agricultural Science and Technology,

Vol.8 Issue.3, March-2021, pg. 10-26

ISSN: 2348-1358

Impact Factor: 6.057

NAAS Rating: 3.77

[88]. Zende, N.B., Sethi, H.N., Karunakar, A.P. and Jiotode, D.J. (2005). Effect of sowing time and fertility levels on yield and quality of durum wheat genotypes. Res. Crops. 6 (2): 192-193.

[89]. Zia ul Hassan, M., Wahla, A.J., Waqar, M.Q. and Ali, A. (2014). Influence of sowing date on the growth and grain yield performance of wheat varieties under rainfed condition. Science Technology and Development 33(1): 22-25.

\section{Brief bibliography of the author}

\begin{tabular}{|l|l|l|}
\hline Name & Tamim Fazily & \\
\hline F/Name & Fazul Ahmad & \\
\hline Date of Birth & $02 / 11 / 1987$ & \\
\hline Place of Birth & Baghlan, Afghanistan & \\
\cline { 2 - 4 } & Occupation & $\begin{array}{l}\text { Associate Professor at Department of } \\
\text { Agronomy, Agriculture Faculty of } \\
\text { Baghlan University }\end{array}$ \\
\hline & Agronomy, CCSHU, Hisar, India & $\mathbf{1 2 . 0 2 . 2 0 2 0}$ \\
\hline PhD & Agronomy, UAS, Dharwad, India & $\mathbf{2 7 / 0 7 / 2 0 1 8}$ \\
\hline M.Sc & $\begin{array}{l}\text { Plant science Agriculture Faculty of } \\
\text { Baghlan, University }\end{array}$ & December 2006 \\
\hline B.Sc & & \\
\hline
\end{tabular}

Co-curricular activities: Attended 10 National and two International conference, seven training programmes and two workshops abroad of my country.

\section{List of Publications}

1. Fazily Tamim (2011). Response of late sown wheat (Triticum aestivum L.) to organic under irrigation. MSc thesis.

2. Fazily Tamim (2011). Effect of different doses of nitrogen and phosphorus on growth, yield and economics of potato (Solanum tuberosom). Thesis for Academic promotion.

3. Fazily Tamim (2014). Effect of integrated nutrient management on growth, yield and quality of wheat. $\mathrm{PhD}$ thesis.

4. Fazily Tamim (2020). Effect of integrated nutrient management on growth, yield and quality of wheat. $\mathrm{PhD}$ thesis, Translated in Persian.

5. Fazily Tamim,. Thakral S.K., Dhaka A.K and Sharma M.K. (2021). Effect of Integrated Nutrient Management on Growth, Yield Attributes and Yield of Wheat. International Journal of Advances in Agricultural Science and Technology. 8(1): 106-118.

6. Fazily Tamim. Thakral S.K., Dhaka, A.K and Sharma M.K (2020). Effect of Integrated use of organic and inorganic sources of nitrogen on nutrient uptake by wheat and soil fertility. International Journal of Current Advanced Research. 9 (2): 21201-21204.

7. Fazily Tamim,. Thakral S.K., Dhaka A.K and Sharma M.K. (2020). Evaluation of yield and economics of wheat under integrated nutrient management. International Journal of Research and Development in Technology. 13(1): 49-53. 


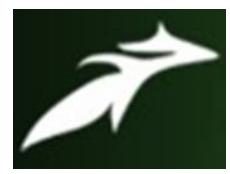

Tamim Fazily, International Journal of Advances in Agricultural Science and Technology, Vol.8 Issue.3, March-2021, pg. 10-26

ISSN: 2348-1358

Impact Factor: 6.057

NAAS Rating: 3.77

8. Fazily Tamim,. Thakral S.K., Dhaka A.K and Sharma M.K. (2020). Impact of Organic and Inorganic Sources of Nitrogen on Growth Phenology, Yield and Quality of Wheat (Triticum aestivum L.). International Journal of Advances in Agricultural Science and Technology. 7(2): 31-38.

9. Fazily Tamim and Hunshal C.S. (2019). Response of late sown wheat (Triticum aestivum L.) to organics. International Journal of Advanced Research and Development. 55-57.

10. Fazily Tamim (2020). Impact of integrated nutrient management on wheat productivity and sustainable soil fertility: A review. EPRA International Journal of Multidisciplinary Research. 6 (1): 236-241.

11. Fazily Tamim. Thakral S.K., Dhaka, A.K and Sharma M.K (2020). Effect of Integrated Nutrient Management on Fertilizer Use Efficiency in Wheat (Triticum aestivum L.) under Irrigated Condition. International Journal of Advances in Agricultural Science and Technology. 7 (2): 1-9.

12. Fazily Tamim, Thakral S.K and Dhaka A.K. Effects of integrated nutrient management on yield attributes and yield of wheat (Triticum aestivum L.) under irrigated condition" published in Golden Jubilee International Conference. Organized by Directorate of Research CCS Haryana Agricultural University on Nov-6-2019.

13. Fazily Tamim, Hunshal C.S., Chimmad V.P, Hebbar Manjunath and Potdar M.P. Response of late sown wheat (Triticum aestivum L.) to organics" published in International Symposium: A need for sustainable Agriculture. Organized by Directorate of Research CCS Haryana Agricultural University on Feb-2-2019.

14. Fazily Tamim and Hunshal C.S. (2019). Effect of Organic Manures on Yield and Economics of Late Sown Wheat (Triticum aestivum L.). International Journal of Research \& Review. 6(1) 168-171.

15. Fazily Tamim (2014). Effect of different doses of nitrogen and phosphorus fertilizers on yield and economics of potato. Pozuhesh Seasonal Magazine Academic and cultural. 6(2):75-82.

16. Fazily Tamim (2019). Integrated Nitrogen Management through Different Sources on Growth and Yield of Wheat (Triticum aestivum L.). Pozuhesh Scientific Journal. 16:45-56.

17. Fazily Tamim and Alemi Muhammad Alem (2019). Effect of different doses of nitrogen and phosphorus on growth and yield potato (Solanum tuberosum L.). International Journal of Advance Research, Ideas and Innovations in Technology. 5(1): 105-107.

18. Fazily Tamim and Habibi Ainullah (2019). Performance of wheat varieties under different dates of sowing under irrigated condition of Baghlan province, Afghanistan. International Journal of Emerging Technologies and Innovative Research. 6:50-53.

19. Habibi Ainullah and Fazily Tamim (2020). Effect of sowing dates on growth, yield attributes and yield of four wheat varieties. International Journal of Research and Development. 5(1): 57-59.

20. Habibi Ainullah, Fazily Tamim and Halimi Abdul Hasib (2019). Varietal response of wheat to water stress condition of Baghlan province, Afghanistan. SSRG International Journal of Agriculture and Environmental Science. 6(3): 43-46.

21. Osmani Mohammad Hakim, Fazily Tamim, Koshani Beheshtah and Mirzaee Mujtaba (2020). Comparison of adaptation assessment of four local spring varieties in Kabul climatic condition. EPRA International Journal of Research and Development. 5 (1):21-23.

22. Wasim Mohammad, Mor V.S., Singh Vikram, Fazily Tamim and Hemender (2020). Morphological Quantitative Characterization of Wheat (Triticum aestivum L.) Genotypes under Normal and Late Sown Conditions. International Journal of Advances in Agricultural Science and Technology. 7 (1): 1-8. 